\title{
Rodney Phillips Dales: influential annelid researcher, natural historian, editor, artist, gardener and architectural enthusiast (1927-2020)
}

\author{
ANDREW S.Y. MACKIE ${ }^{1, *}$, CLARE DALES ${ }^{2}$, R. MICHAEL L. KENT ${ }^{3}$, DAVID R. DIXON ${ }^{4}$, RUFUS M.G. \\ WELLS $^{5}$ \& LYNDA M. WARREN ${ }^{6}$ \\ ${ }^{1}$ Amgueddfa Cymru - National Museum Wales, Cathays Park, Cardiff, CF10 3NP, Wales UK. \\ "'andy.mackie@museumwales.ac.uk, @ (1) https://orcid.org/0000-0003-2308-0595 \\ ${ }^{2}$ Heritage Consultant \& Artist, Eastbourne, Sussex, England UK. \\ ${ }^{3} 53$ Foxdown, Wadebridge, Cornwall, England UK. \\ ”"rmike.kent@tiscali.co.uk, @ https://orcid.org/0000-0002-2552-5327 \\ ${ }^{4}$ Marine Biological Association, The Laboratory, Citadel Hill, Plymouth, Devon PL1 2PB, England UK. \\ झ"drdixon1@btinternet.com, (1) https://orcid.org/0000-0002-1047-1709 \\ 532 Abbotsford Tce, Devonport, Auckland 0624, New Zealand. \\ 巨"rufuswellsnz@gmail.com, @ilttps://orcid.org/0000-0003-4927-710X \\ ${ }^{6}$ Emeritus Professor in Environmental Law, Aberystwyth University, Wales UK. \\ "lyndamwar@gmail.com, ㄴ. https://orcid.org/0000-0002-0520-8367 \\ ${ }^{*}$ Corresponding author
}

Rodney Phillips Dales was born in Hornchurch, Essex on 15 January 1927. His father Sidney Phillips Dales was a Chartered Architect, his mother Muriel Emily (née Tattersall) kept the family home in the Squirrel's Heath district, and frequently worked in her husband's practice. Rodney and his brother Gordon (b. 1922) were raised in a strict Methodist family. They led a modest life, but one full of interest and diversion. Frequent trips to the seaside, and visits to buildings and artist friends of his father, helped shape Rodney's interests and future career. He became fascinated by the diversity of the natural world and the wonderful architecture he encountered on his frequent bike rides into the Essex countryside.

On completing his secondary education in Brentwood, Essex, at 17 (because there was nothing left to teach him), Rodney went to Queen Mary College, University of London, to study Zoology. He completed his undergraduate course and became a PhD student with Gordon E. Newell, a great teacher and enthusiastic supervisor. Queen Mary College maintained a small field facility at Whitstable on the north Kent coast, near Newell's home (Evans 1997; Moore 2009), and his students frequently visited both. Newell's son, Richard, remembers this and later visits by Rodney - "a great character who made numerous visits to our family home at Poplar Hall, just outside of Faversham in Kent" (R. Newell, pers. comm.). Indeed, Gordon acknowledged Rodney's help in finding what appeared to be the Northeast American acorn worm Saccoglossus kowalevskii on Whitstable flats (Newell 1949). Gordon Newell died in 1968 (Anon 1968), however, prior to this, his son Richard (lecturer, University of London 1962-74) became station Director. The station closed in 1971/72 when the lease from the old Royal Native Oyster Company was relinquished; it is now a seafood restaurant. The closure was mainly due to staff changes and a decreased interest in Marine Biology at Queen Mary (R. Newell, pers. comm.). In addition, the University of London had already (1970) formed a partnership with the University of Glasgow to run the far larger Millport Marine Station on the west coast of Scotland (Moore 2009).

At Queen Mary College Rodney became life-long friends with John E. Morton and Roy Freeman. Coincidently, Freeman later became a lecturer at the College and supervised Richard Newell when he was an undergraduate. Both John Morton and Roy Freeman subsequently took up academic posts in New Zealand as Professors of Zoology at the University of Auckland (1959) and University of Otago (1968) respectively. John Morton (1924-2011) would go on to become one of New Zealand's greatest marine scientists (B. Morton 2011; Gordon \& Ballantine 2013).

As befitted a long-time resident of the appropriately named Squirrel's Heath, Rodney was an enthusiastic naturalist with many diverse fields of interest. His first published article, in Nature no less, was on the 
occurrence of the parasitic thorny-head worm Acanthocephalus ranae in the gut of a common frog used for laboratory dissection (Dales 1948). In the late 1940s and early 1950s he joined a number of societies and institutions, including The Marine Biological Association of the United Kingdom, British Ecological Society, and Zoological Society of London. He published a paper on a simple trap for Craneflies (Dales 1953), was involved in UK Beetle Recording, and participated in a survey of the numbers of the Great Crested Grebe in Britain (Hollom 1951).

\section{Postgraduate period}

Rodney successfully presented his $\mathrm{PhD}$ thesis The biology of some littoral polychaetes in 1950 . The United States Fulbright programme provided travel grants to UK citizens for the purposes of study, research or lecturing at American institutions of higher learning. Rodney received a grant to study at Scripps Institution of Oceanography, University of California at La Jolla. He set sail on the RMS Queen Elizabeth from Southampton (to New York) on 14 September 1950. Scripps would be his research home for almost a year. He carried out varied studies on the opheliid Thoracophelia mucronata, the sabellariid Phragmatopoma californica, as well as pelagic polychaetes and heteropod molluscs from US survey collections. Papers on these appeared, along with several from his $\mathrm{PhD}$ work, over the following 5 years or so. Furthermore, this visit created a long-standing affection for the west coast of America. He seized the opportunity of the adventure and travelled, often with his bike, to explore the mountains and deserts and the diverse marine wildlife of the west coast. He discovered music, wine and, being naturally sociable, he found friends everywhere. He camped with the Navaho in 1950, and visited many of modernist Richard Neutra's houses, igniting further his fascination with architecture. Rodney would return several more times in the 1950s and early 1960s for research and lecturing (augmented by leisure) purposes at the University of California, Santa Barbara, and the Friday Harbor Laboratories, University of Washington. He returned to Southampton on the RMS Queen Mary on 11 September 1951. He could hardly imagine that 17 years later the Queen Mary would end her days in Long Beach, California, and become a tourist attraction, hotel and museum - far less that the ship would be the venue for the $13^{\text {th }}$ International Polychaete Conference in 2019!

Rosalind Franklin returned to England from working in Paris in 1951. She had been awarded a TurnerNewall Fellowship to work at King's College London (Bernal 1958). Rodney briefly worked for her when she was employing X-Ray crystallography in research that was to contribute so much to the discovery of the structure and understanding of DNA. Just prior to this, in 1950, Sir John Cass College came into being when the Sir John Cass Technical Institute (since 1902) broadened its courses, upgrading some to University standard. Rodney secured a position there as Zoology Lecturer and ambitions were high.

One of the papers Rodney published at this time was a collaboration with George Philip Wells on the irrigation of the burrows of Chaetopterus variopedatus and Nereis diversicolor (Wells \& Dales 1951). Wells was the son of the science fiction author H.G. Wells, and an authority on Arenicolidae. Rodney contributed several reminiscences to a biographical memoir for Wells following his death in 1985 (Fogg 1986), including "I remember challenging him on some point of Arenicola biology and received, by return of post, a picture postcard of the armoury in the Tower - scribbled on the back was an invitation to talk over lunch at the Savile Club. This was typical."

In 1953, Rodney wrote to the brilliant J.B.S Haldane at the University of London requesting 'old reprints relating to zoology' (archive letters at https://wellcomelibrary.org). His address was given as 'Zoology Museum at Sir John Cass College'. The renowned entomologist Laurence Mound (Funderburk \& Hoddle 2011) was studying Marine Biology at the college (1953-57) and believes the Zoology Museum was "a bit of an invention", perhaps an aspiration, as he has "no memory of any substantial collections at Cass" (Mound, pers. comm.). Mound remembers Rodney as "a kind and mild mannered man who always had enough time" and that, when he left for Bedford College in the mid 1950s, "Zoology at Cass was much weaker without him". Further insights into Rodney's character were revealed when, in 1957, Mound asked him for a reference in support of his application for a Colonial Service postgraduate scholarship. Rodney "smiled at my enthusiasm for progressing into economic entomology and 'doing something useful' $\ldots$ in his usual down-beat way he smiled and said 'I am glad that no one could ever say that my work [on polychaete pigments] is useful' ." One of the last papers he published while at Sir John Cass College was The evolution of the pelagic alciopid and phyllodocid polychaetes (Dales 1955). This was particularly significant since it was the first time he had examined phylogenetic relationships in a group of polychaetes. 


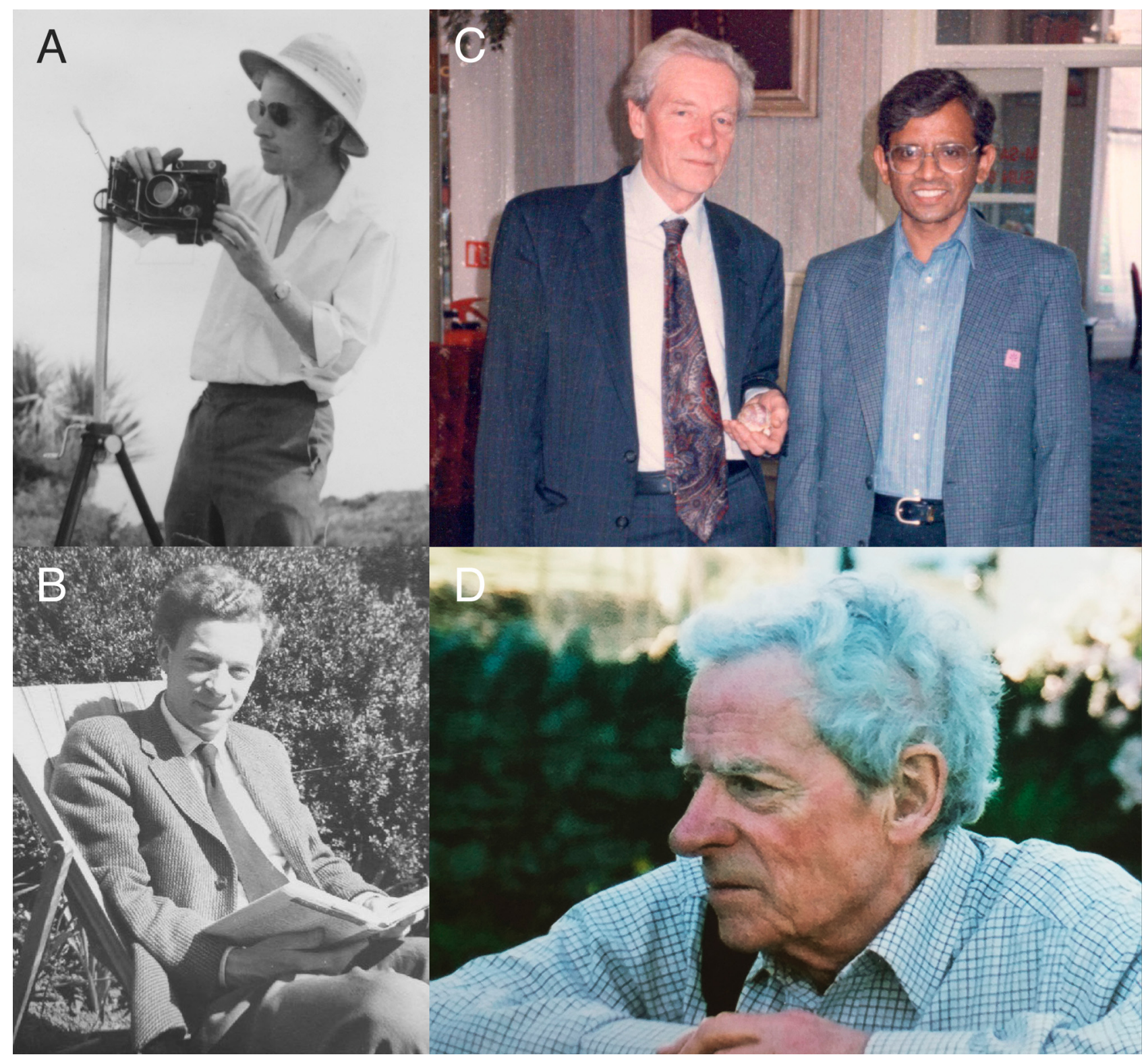

FIGURE 1. Rodney Dales. A, Arizona 1950s; B, relaxing at home, late 1940s or 1950s; C, with Javed Mustaquim at The Natural History Museum, London, 1999; D, on holiday 1995 (Photos: A, B \& D, Clare Dales; C, Javed Mustaquim).

\section{Bedford College}

Professor Norman Millott was appointed as Head of Zoology at Bedford College, University of London, Regent's Park, in 1955 and he brought in Rodney as Assistant Lecturer to expand the Department. Zoology was housed on the top floor of the Darwin Building. Within a year, Rodney was moved into the lectureship and two additional Assistant Lecturers were employed (Dales \& Gilchrist 1987). The late 1950s and into the 1960s was a time of expansion, and additional appointments and internal structural changes were made. An increasing emphasis on invertebrate biology led to Marine Biology being offered as a special subject under Rodney. Field trips included visits to the Queen Mary Whitstable Laboratory and the University College of Wales at Swansea, where Wyn Knight-Jones was Professor of Zoology (Mackie et al. 2014). Rodney became a great friend of Wyn and his wife Phyllis (Mackie et al. 2011). At Bedford, Rodney continued publishing an everwider range of papers, book chapters and articles, primarily concerning polychaetes; e.g., on pelagic species, feeding, anatomy, ultrastructure, commensalism, osmotic regulation, physiology, biochemistry, respiration, haemoglobin, pigments, lipids. His first contribution to New Scientist was entitled Ragworms and Caviar (Dales 1957). The brief biography associated with this ended with "His interests range from ballet to early music and include 'cathedral-gazing.' "“ 
In January 1959 Rodney married Margaret Elizabeth Kidd, a teacher, in Plymouth. They made their home in Horsham, Sussex, and four years later bought a Grade II listed farmhouse. The house, believed built between 1450 and 1485, was badly in need of renovation. Rodney set about this with a passion and almost singlehandedly transformed the house and garden into a characterful family home. Rodney and Margaret would go on to have five children together in a long and happy marriage. In June 1959, Rodney sailed to the USA to be a summer visiting lecturer at the NSF Institute in Marine Science at the University of California, Santa Barbara. On July 21 he gave an All-College talk On Living in Sand: Problems of Life on the Beach (Anon 1959). Margaret joined him in the USA for the last 3 weeks of the trip. The following June, Rodney flew to New York en route to Friday Harbor for a research visit that generated several papers on terebellids and sabellids. Margaret sailed to Montreal in late July and, two months later, they sailed back together from New York to Southampton. In future years they travelled extensively together and with the family. Rodney always had a sketchbook by his side and often snuck off on family holidays to create wonderful pen and ink and watercolour drawings of the port at Guilvinec in Brittany, the peaks of the Alps, or the flora of the Gower Peninsula in South Wales.

"If the Fifties were in black and white, then the Sixties were in Technicolor" (Watson 2016). It was a decade of rapid change for all aspects of society. Rodney and Margaret's respective interests in ballet and opera meant they attended many productions at the Royal Opera House and other venues. At the same time the 1960s marked a great increase in both Rodney's workload at Bedford College and in his publication output. Additional staff were appointed throughout the decade as the College broadened its scope, and a better balance between invertebrate and vertebrate teaching and research was achieved. Rodney was awarded a personal Readership in 1965-66 (Dales \& Gilchrist 1987). He published extensively and reviewed several important books, including Laverack's Earthworm Physiology in 1963 and Day's two volume A Monograph on the Polychaeta of Southern Africa in 1968.

In 1962 he published The polychaete stomodeum and the inter-relationships of the families of Polychaetaan important work for many polychaete researchers. Criticised by some (e.g., Orrhage 1973) this publication had a significant influence on those who would go on to develop their own ideas on polychaete phylogeny (e.g., see Fauchald \& Rouse 1997; Rouse \& Fauchald 1997). Fifteen years later, Rodney addressed some of the earlier criticisms in his The polychaete stomodeum and phylogeny contribution to the Olga Hartman memorial volume (Dales 1977). The second important work he produced in the early 1960s was his book, Annelids (Dales 1963). Much of this was written on the train on his way to work (Chris Mettam, pers. comm.) and it became a go-to reference book for any student wanting to learn about the group. Again, there were some critics. In two reviews, Tebble $(1963,1964)$ believed the book too polychaete orientated, too physiologically based, and he even doubted the necessity of including a phylogenetic chapter! Wells (1964) thought it would "provide valuable stimuli for the student who wants something to think about", but lamented a number of factual errors. However, reviews by Brookhout (1964) and Moment (1964) were overwhelmingly positive. Annelids was a great success with students, and a second edition appeared in 1967 (reprinted 1970). Barnes (1969) described the book succinctly as "A general biology of the annelids, with special emphasis on the polychaetes."

Rodney illustrated many of his research papers with his own beautiful line drawings, which he also used in his lectures. He approached most things in life with humour. He had a particular slide for use in undergraduate lectures of a worm with two heads (it gets confused), a worm with two tails (it gets bored), and a worm with both parts (just to see if you are awake at the back!). He was modest and never one to imply that a specific understanding was beyond the scope of anyone who was interested. Studying marine worms whilst based in London necessitated frequent trips to the Marine Biological Association in Plymouth in order to collect specimens. Equipped with Wellington boots, garden forks and collecting boxes, Rodney and his students gathered such wonders as the bright red Terebella lapidaria and his favourite worm, Neoamphitrite figulus.

The Larouse Encyclopedia of Animal Life (1967) was an ambitious reworking of Bertin's La Vie des Animaux (1949) involving a number of British authors. Rodney contributed chapters on sipunculans, echiurans and annelids to this impressive one-stop reference volume aimed at a public audience. Reviews by Oppenheimer (1967) and Gray (1967) were favourable, with the latter describing it as "unquestionably the best singlevolume encyclopedia of zoology currently available." He nevertheless had a few quibbles, and commented on the imbalance between the larger page representations for invertebrates, and birds and mammals, when compared to those for fish, amphibians and reptiles.

At this time, Rodney was General Editor for Sidgwick \& Jackson's Biology Series which produced a number of important and influential works. Green's The Biology of Estuarine Animals (1968) and Robert McNeill Alexander's Animal Mechanics (1968) were followed by Dales's own Practical Invertebrate Zoology 
(1969) and a translation of Friedrich's Marine Biology (1969), already a standard work in the original German (Meeresbiologie 1965).

Alexander (1989) recalled how Rodney wrote to him in 1966, inviting him to write a book on "the mechanics of animal structures". He accepted, had a contract within two weeks, and Animal Mechanics was published two years later. It was very well received and quickly regarded a classic work. Blackwell Scientific published a second edition in 1983. Rodney acted as both editor and contributing author in producing Practical Invertebrate Zoology (Cox et al. 1969). This useful book was firmly aimed at students and teachers, and was designed as a companion to, rather than a replacement for, works such as Barnes' Invertebrate Zoology (1968, and subsequent editions). It was an impressive and valuable practical manual, full of useful information on appropriate methods (narcotisation, fixation, staining, slide preparation, dissection, experimentation, anatomy and live maintenance). It presented an outline classification and was predominately illustrated with original line drawings made by the authors. Rodney contributed chapters on Coelenterates, Ctenophores, Annelids, Echiuroids, Sipunculids, Lophophorates and Insects, and a section on Endoprocts. Reviews by Trueman (1969) and Dustman (1970) were positive, but Harman (1971) was more critical. A second edition was published in 1981. Rodney was external examiner for the $\mathrm{PhD}$ theses Aspects of polychaete skeletomuscular systems by Chris Mettam (1969) and Reproductive biology of the polychaete Melinna cristata off the Northumberland coast by Pat Hutchings (1970).

As the Sixties came to a close much had changed and the Seventies promised even more. Society had become more confident, vibrant and, to a large extent, more informal. Rodney was now known to his colleagues, peers and students by his nickname 'Dos', rather than Rodney. While it would have been known to close friends and family, 'Dos' was certainly not current in Fifties academia. Mound (pers. comm.) recalls "students were very polite to lecturers such as Dr Dales in the 1950s. Socially we had more in common with the 1930s than the 1970s." Many of his students in the late 1960s and 1970s thought the nickname was acquired at school, perhaps from Greek classes, or from his answer at roll-call. However, Lynda Warren recalls asking him directly, "Number two son" was his reply.

\section{Head of Department}

Professor Millott resigned from Bedford in 1969 and became the first Director of the University Marine Biological Station Millport (Dales \& Gilchrist 1987). He enjoyed some happy years there before his retirement in 1976 (Moore 2009). Following Millott's resignation, Rodney was appointed Acting Head of Department, becoming Chair in 1971. He moved into the corner room of his two predecessors overlooking Queen Mary's Rose Garden; "perhaps the best view of any on the whole site" (Dales \& Gilchrist 1987).

Rodney delivered his Inaugural Lecture In Praise of Zoology in June 1973. The Lecture was wide-ranging, but he was firm in his beliefs that science was an intellectual pursuit, that the role of Universities (and other institutions) was "to further knowledge by fundamental research, and to teach those who wish to know," and that "a society presuming to be civilised should have a real regard for scholarship." Further, scientific research couldn't be directed toward a defined goal - rather, discoveries came from basic science and the pursuit of truth. He recognised the distinction between pure and applied science, while acknowledging the two-way interaction between them. Hence, he decried the call of science to justify itself and the influence of 'cost effective' - conscious bureaucrats.

The centrepiece of the lecture was a stunning example of research in support of all the above, and of his lateral thinking. The starting point was a simple question; why were some individuals of the intertidal terebellid Neoamphitrite figulus orange, and others brown? Rodney first demonstrated that the biosynthetic pathway to haemoglobin synthesis in the polychaete was irregular, and that the brown pigment produced both accumulated with age and provided protection from sunlight. However, he also realised that the situation in Neoamphitrite was a form of Porphyria similar to one of the disorders found in man. This realisation revealed the biosynthetic pathway connection with the hereditary Porphyria disease believed to have afflicted King George III (17381820) and traceable back to Mary Queen of Scots (1542-1587)! In 1991, the playwright Alan Bennett wrote a play The Madness of George III, later (1994) made into a film, The Madness of King George.

The lecture concluded with his visions on how recent developments of microtechniques could lend new dimensions to our knowledge of all aspects of even the smallest invertebrates. The growing impact of human activities on environments would surely be minimised or avoided by increasing our understanding of the lives and requirements of the animals that reside therein. 
The Zoology Department was now at its maximum complement of 8 members of staff. The Tuke-Darwin infill was built and the Department gained extra laboratory and technical space on the top floor. Additional areas in the basement provided a large research laboratory for up to 15 postgraduate students in the Seventies, as well an animal house and an aquarium (Dales \& Gilchrist 1987). Notable PhD students studying annelids were Rufus Wells (1974: polychaete respiratory physiology), Lynda Warren (1975: biology of Capitella) and David Dixon (1977: energetics of Mercierella enigmatica). In many ways, the early to mid 1970s period was the best of times. Rodney created a 'family atmosphere' in the Department where lecturers, technicians, research assistants and $\mathrm{PhD}$ students were all valued. For a number of years Rodney invited them all to a summer barbecue at his home.

Rodney was very hands-off as a supervisor and gave his students a lot of latitude to get on with their studies. Nevertheless, he would always give them encouragement and often carried out great acts of kindness to help them for their future careers. Mike Kent, a former Bedford undergraduate (1969-73), recalls how Rodney kept faith in him after he failed to get his desired $\mathrm{PhD}$ qualifying grades and helped him get a place on the Marine Biology MSc course at the Menai Bridge Marine Laboratory, Bangor University, in northwest Wales. Following this, Mike obtained a Research Assistantship at Plymouth Polytechnic and registered as a PhD student investigating the infestation of mollusc shells by Polydora; Rodney kindly agreed to be his required external supervisor (Kent 1977). Mike entered the teaching profession, first at Torpoint School, then at St Austell and Cornwall College where he helped establish the Centre for Applied Zoology. He wrote several science textbooks including Advanced Biology (2000) and his latest, The Marine Environment and Biodiversity, is nearing completion. In 2018, Mike was elected a Fellow of the Royal Society of Biology for work in education.

Rufus Wells, after graduating, was surprised to learn that Rodney had found him a job as a clinical biochemist at University College Hospital Medical School to work on oxygen transport during early embryonic development! Thinking of an embryo as a "worm in the womb" led to new discoveries about preplacental respiration in mammalian development. Rodney later supported his application for a lectureship back at Auckland University where he spent most of his career, becoming Professor of Biological Sciences and following in the footsteps of his Honours supervisor John E. Morton. He is a Fellow of the Royal Society of New Zealand. Lynda Warren was both a student and three-times Postdoctoral Researcher with Rodney. He somehow persuaded the grant awarding body of one of the postdoc positions to recognise her as Principal Investigator. Lynda subsequently obtained a Batchelor of Laws degree (University of London) in 1986 and an MSc in Marine Law and Policy (Cardiff University) in 1989, becoming a Senior Lecturer at Cardiff University (1989-1996). She is Emeritus Professor of Environmental Law at Aberystwyth University, Honorary Professor at Bangor and Birmingham Universities, Fellow of the Learned Society of Wales and, in 2017, was awarded an OBE for services to the environment at home and abroad.

Throughout his career Rodney was well-connected with researchers in other institutions, and his students would meet and be introduced to many famous Marine Biologists. This is how David Dixon first met Alan and Eve Southward at the Marine Biological Laboratory in Plymouth and, after completing his $\mathrm{PhD}$, was then invited to work with Alan on the uptake of dissolved amino acids by pogonophorans. After a short period, he and his wife Linda (née Caskie) — who had been Rodney's research assistant working on polychaete blood cells - moved to Plymouth on a permanent basis. David joined the NERC Institute for Marine Environmental Research (now Plymouth Marine Laboratory) working on a range of invertebrate species in a research group "devoted to all things" Mytilus edulis. In 1997, David moved to Southampton Oceanography Centre (now the National Oceanographic Centre) as Head of Molecular Genetics. While leading an EU-funded research programme (VENTOX), he and Linda helped pioneer the use of retrievable cages in deep-sea hydrothermal vent research which led to the discovery of seasonal reproduction in the Atlantic vent mussel Bathymodiolus azoricus (Dixon et al. 2006). Now retired, David and Linda maintain their links with the Marine Biological Laboratory in Plymouth.

Rodney's publications continued to flow throughout the 1970s on a range of subjects, including annelid physiology, anatomy, respiration and respiratory pigments, graft rejection, bioluminescence, anti-bacterial defence mechanisms and Eastern Pacific Spirorbidae. He produced A synopsis of the pelagic Polychaeta (Dales \& Peter 1972) and revisited The polychaete stomodeum and phylogeny (Dales 1977). He was a prolific reviewer of books for Nature.

Despite all this success, darker days loomed for Bedford College. Declining resources made it clear that the smaller London colleges were under threat. It was proposed that Bedford and Royal Holloway Colleges should merge (Dales \& Gilchrist 1987); Rodney diplomatically kept his views from print. His predecessor Norman Millott was known to be very hostile to any such merger (Moore 2009). 


\section{Bedford-Royal Holloway merger}

The early 1980s was a difficult and stressful time for all at Bedford College. The merger began in 1982, and for two years Bedford staff had to teach at both the Regent's Park site and Royal Holloway College at Egham, Surrey, 19 miles west of Central London. Much of 1983-84 was taken up by organising the dismantling of the Bedford laboratories and their transfer to Egham (Dales \& Gilchrist 1987). The 'Royal Holloway and Bedford New College' was officially established in 1985 and inaugurated by Queen Elizabeth II the following year. This remains the official registered name, however, the College Council changed it in 1992 to 'Royal Holloway, University of London' for day-to-day use. A School of Life Sciences was created in 1987 and comprised two Departments - Biology and Biochemistry. Rodney became Head of Biology, an amalgamation of the Botany and Zoology departments of both colleges.

Academic life continued despite the disruption and Rodney continued to produce papers and book chapters on a variety of annelid subjects (1980-85), including invertebrate immunology (Dales \& Dixon 1980, 1981; Dales 1983). His PhD student Javed Mustaquim completed his thesis on Polydora ciliata (Mustaquim 1982). That same year he published a book on The Older Houses of Warnham (Dales 1982), which he described as "only an introduction" to the timber-framed buildings there. Publications decreased markedly after the formation of the new college and his last 'annelidan' PhD student submitted her thesis on agglutinins in the oligochaete Eisenia foetida (Bennett 1989). Nevertheless, British Phyllodocoideans, Typhloscolecoideans and Tomopteroideans with co-author Fredrik Pleijel (1991) was a major achievement. The book in the renowned Synopses of the British Fauna series was a collaboration almost completely written apart. Pleijel (pers. comm.) recalls "I actually met Rodney only once. It had been agreed that we two should co-author the volume ... covering holopelagic polychaetes and benthic phyllodocids. Rodney had the former section and I had the latter. We met to go through the text and once this was done we went for a collecting trip at low tide. I cannot remember which beach it was, but I was impressed: he was a very gentle and knowledgeable man and belonging to a disappearing generation with a wide knowledge in all fields of marine biology."

\section{Species honours}

Two species were named for Rodney, the maldanid polychaete Clymenella dalesi Magnum, 1966 from Brazil, and Sabellacheres dalesi Green, 1961, a copepod parasite of the sabellid Eudistylia polymorpha from California, USA. The second was transferred to the genus Gastrodelphys as Gastrodelphys dalesi by Dudley (1964).

\section{Retirement}

Rodney retired in 1992 after a long and highly influential career as a marine zoologist, specialising predominately in the study of marine annelids. Following retirement, he contacted Chris Mettam (Cardiff University) looking for a suitable home for his reprint collection. Chris kindly passed the enquiry to the lead author and it was subsequently agreed that the National Museum Wales would purchase them. The extensive Dales reprint collection instantly became the core literature resource for annelid research at the Museum and is in constant use to the present day.

Once retired, Rodney and Margaret travelled extensively, and he pursued all his interests with typical energy and undiminished curiosity. He obtained a Degree in Fine Art Printmaking, followed by Printmaking at The Slade School of Fine Art, where he was a top student, producing fabulous work. His long-standing passions for gardening, particularly Geraniums, and architecture continued unabated. At one time it was believed that he essentially had the national collection of Geraniums in his garden. He contributed to Geraniaceae Group News (e.g., Dales 2007, Dales \& Clifton 2007) and supplied certain interesting plants to experts such as Peter Yeo, author of Hardy Geraniums (Yeo 2005: 185).

He retained his interest in science, answering a question in New Scientist on the nature of the pink colour of flamingos (Dales 2003) and, in a hand-written letter to the editor (Dales 2012) of JMBA Global Marine Environment (the forerunner of The Marine Biologist magazine) wrote "Dear Dr Pulsford, I would like to congratulate you on the truly 'global' Global - all the articles interesting \& informative! I became a life member of the MBA around 1948 \& still greatly look forward to the newsletters \& Journal. I wish I could 
start again! With kind regards, Sincerely, Rodney Dales". For an investment of 20 guineas that was a bargain membership!

He continued to write. Rodney's last published work (Dales 2018) The Buildings of Warnham: A history of a parish in the Weald of West Sussex was a true labour of love and an astonishingly detailed reference book. The book was dedicated "In memory of my father S. Phillips Dales FRIBA 1883-1971 to whom I owe so much". He was writing up until three weeks of his death - a philosophy book, and a series of short stories for his granddaughter. Rodney passed away from natural causes after a short illness on 14 February 2020. He is survived by his wife Margaret and three of their five children, and by two granddaughters and three grandsons. Two sons predeceased him.

\section{Tributes}

Bridget Baker, who studied Zoology at Bedford College with Margaret, writes "I first knew him when I was a student at Bedford College. I remember most vividly his lectures on insects which were really excellent. He would describe some feature or function and then say 'of course you could already have known that because ...' and show how one could deduce facts about an animal from isolated observations. As an undergraduate, I found that inspirational."

Rodney was well-known to many of the current generation of polychaete researchers, though unfortunately few had met him. As with Fred Pleijel, the lead author only met him once-when collecting his reprints for the National Museum Wales. A most enjoyable lunch was had together, and it was an honour to meet him and chat about polychaetes.

Greg Rouse (Scripps Institution of Oceanography) writes "I regret that I never had a chance to meet Rodney Dales. His work was wide-ranging and consistently excellent. I have found throughout my career that any paper of his I saw referenced would be worth retrieving. His paper The polychaete stomodeum and the interrelationships of the families of the Polychaeta is still essential reading for anyone interested in annelid phylogeny and his 1963 volume Annelids is still a handy resource of the knowledge on annelid anatomy and physiology up until that time."

Kirk Fitzhugh (Natural History Museum of Los Angeles County) was similarly influenced: "In the early to mid ' 80 s my interest shifted from benthic ecology to systematics. Especially due to lengthy discussions with Kristian [Fauchald], and learning about 'cladistics' at the start of my PhD (at George Washington University), I had a growing interest in polychaete phylogenetic relationships. Naturally, Dales' work on polychaete evolution was required reading. His thinking, along with that of Kristian, Meredith Jones, Chris Mettam, among others, provided me foundations for developing my own ideas. We all stand on the shoulders of giants."

Günter Purschke (Universität Osnabrück) writes "I know him from the literature and his numerous contributions to polychaetes. My references to him stop in the late $80 \mathrm{~s}$ with his papers on the function and structure of the heart body in various annelids. First of all I think his daughter is right that his small book on annelids is still a good introduction to this group and a very good summary of what was known at that time point. However, it suffers from a too small number of illustrations I think. I had a copy of this book from the beginning of my own work with these creatures but recently I got the opportunity to buy an original from a second-hand bookshop. Although having been criticized by many others his paper on the polychaete stomodeum (Proc. Zool. Soc. Lond 139, 1962) is another valuable contribution to the relationships of polychaetes. At that time it gave a new and different look on polychaete relationships and some ideas written in this paper were important to stimulate colleagues for further investigations and discussions. The third aspect I correlate with him are his various and valuable contributions to the vascular and respiratory system and heart body."

The last word should rightfully go to Javed Mustaquim, one of his later PhD students and now former Director and Professor of the Centre of Excellence in Marine Biology, University of Karachi, Pakistan. "Professor R.P. Dales was my PhD supervisor for four years, from May 1978 to May 1982. It was a great pleasure to work with him. He was a smart, well-organized and self-disciplined person. He did not think of teaching and research as a job, the passion and immense love he had for his profession remained unmatched. Besides being a great teacher and researcher, he was a humble man, a kind soul, who helped people in a way that would not make them feel any less equal than others. He was unique in his ability to manage crises with cool-headedness and presence of mind. He had immense respect for his colleagues and students. He used to treat everyone around him as a friend, as a family member. He was not just my research supervisor, but a friend and a mentor who instilled his expertise, abilities and confidence into me. I am deeply saddened by his passing." 


\section{Acknowledgements}

We are very grateful to Greg Rouse for proposing that this obituary be written for the Proceedings of the $13^{\text {th }}$ International Polychaete Conference. Ironically, the current pandemic meant the lead author could not access the Dales Reprint Collection in the National Museum Wales (NMW). He would like therefore to thank the School of Ocean Sciences, Bangor University and, in particular, John Turner, Chris Richardson and Stuart Jenkins for the electronic library access afforded him during his time as an Honorary Senior Lecturer. This was vital in obtaining the necessary literature and formulating the references. Likewise, he thanks Julian Carter (NMW), and Keith Hiscock, Sarah Nichols, John Bishop (Marine Biological Association, Plymouth) for their efforts in trying to obtain some elusive references. Richard Newell (Richard Newell Associates), Lawrence Mound (Australian National Insect Collection, CSIRO Black Mountain), Chris Mettam (Cardiff University), Geoff Moore (University Marine Biological Station Millport) and Bridget Baker provided much useful information on Rodney's career. Thanks also to Javed Mustaquim, Greg Rouse, Kirk Fitzhugh, Fred Pleijel, Günter Purschke for their tributes, to Linda Dixon (Marine Biological Association, Plymouth) for her memories and text contributions, and to Kate Mortimer and Mike Wilson (NMW) for their helpful comments on the manuscript. Final thanks go to Janet Mackie for her excellent genealogical and 1950s detective work.

\section{Publications (by year)}

Dales, R.P. (1948) Occurrence of Acanthocephalus ranae Schrank. in Great Britain. Nature, London, 162 (4130), 1001. https://doi.org/10.1038/1621001a0

Dales, R.P. (1950) The biology of some littoral polychaetes. PhD thesis, Queen Mary College, University of London, 247 pp.

Dales, R.P. (1950) The reproduction and larval development of Nereis diversicolor O.F. Muller. Journal of the Marine Biological Association of the United Kingdom, 29 (2), 321-360. https://doi.org/10.1017/S0025315400055405

Dales, R.P. (1951) An annual history of a population of Nereis diversicolor O. F. Müller. Biological Bulletin, Woods Hole, 101 (2), 131-137. https://doi.org/10.2307/1538379

Wells, G.P. \& Dales, R.P. (1951) Spontaneous activity patterns in animal behaviour: the irrigation of the burrow in the polychaetes Chaetopterus variopedatus Renier and Nereis diversicolor O.F.Muller. Journal of the Marine Biological Association of the United Kingdom, 29 (3), 661-680. https://doi.org/10.1017/S0025315400052851

Dales, R.P. (1951) Notes on the reproduction and early development of the cirratulid Tharyx marioni (St Joseph). Journal of the Marine Biological Association of the United Kingdom, 30 (1), 113-117. https://doi.org/10.1017/S0025315400012613

Dales, R.P. (1951) Observations on the structure and life history of Autolytus prolifer (O.F.Muller). Journal of the Marine Biological Association of the United Kingdom, 30 (1), 119-128. https://doi.org/10.1017/S0025315400012625

Dales, R.P. (1952) The larval development and ecology of Thoracophelia mucronata (Treadwell). Biological Bulletin of the Marine Biology Laboratory, Woods Hole, 102, 232-242. https://doi.org/10.2307/1538371

Dales, R.P. (1952) The development and structure of the anterior region of the body in the Sabellariidae, with special reference to Phragmatopoma californica. Quarterly Journal of Microscopical Science, 93 (4), 435-452.

Dales, R.P. (1953) North-East Pacific Phyllirhoidae. Annals and Magazine of Natural History, Series 12, 6 (63), $193-194$. https://doi.org/10.1080/00222935308654411

Dales, R.P. (1953) The distribution of some heteropod molluscs off the Pacific coast of North America. Proceedings of the Zoological Society of London, 122 (4), 1007-1016. https://doi.org/10.1111/j.1096-3642.1953.tb00359.x

Dales, R.P. (1953) A simple trap for Tipulids (Dipt.). Entomologist's Monthly Magazine, 89, 304.

Dales, R.P. \& Kennedy, G.Y. (1954) On the diverse colours of Nereis diversicolor. Journal of the Marine Biological Association of the United Kingdom, 33 (3), 699-708. https://doi.org/10.1017/S0025315400026977

Chapman, G. \& Dales, R.P. (1954) Aspects of the fauna and flora of the Azores. II. Polychaeta. Annals and Magazine of Natural History, Series 12, 7 (81), 678-683. 
https://doi.org/10.1080/00222935408651775

Dales, R.P. (1955) Feeding and digestion in terebellid polychaetes. Journal of the Marine Biological Association of the United Kingdom, 34 (1), 55-79.

https://doi.org/10.1017/S0025315400008614

Dales, R.P. (1955) The evolution of the pelagic alciopid and phyllodocid polychaetes. Proceedings of the Zoological Society of London, 125 (2), 411-420.

https://doi.org/10.1111/j.1096-3642.1955.tb00607.x

Dales, R.P. (1955) The pelagic polychaetes of Monterey Bay, California. Annals and Magazine of Natural History, Series 12,8 (90), 434-444.

https://doi.org/10.1080/00222935508656070

Dales, R.P. (1956) An annotated list of the pelagic Polychaeta. Annals and Magazine of Natural History, Series 12, 9 (100), 289-304.

https://doi.org/10.1080/00222935608655815

Dales, R.P. (1957) Pelagic polychaetes from the Bay of Biscay. Annals and Magazine of Natural History, Series 12, 10 (117), $661-664$.

https://doi.org/10.1080/00222935708656010

Dales, R.P. (1957) The feeding mechanism and structure of the gut of Owenia fusiformis delle Chiaje. Journal of the Marine Biological Association of the United Kingdom, 36 (1), 81-89. https://doi.org/10.1017/S0025315400017082

Dales, R.P. (1957) Preliminary observations on the role of the coelomic cells in food storage and transport in certain polychaetes. Journal of the Marine Biological Association of the United Kingdom, 36 (1), 91-110. https://doi.org/10.1017/S0025315400017094

Dales, R.P. (1957) Some quantitative aspects of feeding in sabellid and serpulid fan worms. Journal of the Marine Biological Association of the United Kingdom, 36 (2), 309-316. https://doi.org/10.1017/S0025315400016817

Dales, R.P. (1957) Chapter 15. Interrelations of Organisms. A. Commensalism. In: Hedgepeth, J.W. (Ed.), Treatise on Marine Ecology and Paleoecology. Memoirs of the Geological Society of America, 67 (1), 391-412. [https://pubs.geoscienceworld. org/books/book/73/chapter/3787111/A-Commensalisms]

Dales, R.P. (1957) Pelagic polychaetes of the Pacific Ocean. Bulletin of the Scripps Institution of Oceanography of the University of California, 7 (2), 99-167.

Dales, R.P. (1957) Ragworms and caviar. New Scientist, 3 (53), 22-23 \& 50.

Dales, R.P. (1957) Zooplankton. Sheet 66. Heteropoda. Families: Atlantidae, Carinariidae, and Pterotracheidae. Conseil International pour L'Exploration de la Mer, 4 pp. Available from: https://doi.org/10.17895/ices.pub.4992 (accessed 3 June 2020)

Jørgensen, C.B. \& Dales, R. P. (1957) The regulation of volume and osmotic regulation in some nereid polychaetes. Physiologia Comparata et Oecologia, 4, 357-374.

Dales, R.P. (1958) Survival of anaerobic periods by two intertidal polychaetes, Arenicola marina (L.) and Owenia fusiformis Delle Chiaje. Journal of the Marine Biological Association of the United Kingdom, 37 (2), 521-529. https://doi.org/10.1017/S0025315400023845

Kennedy, G.Y. \& Dales, R.P. (1958) The function of the heart-body in polychaetes. Journal of the Marine Biological Association of the United Kingdom, 37 (1), 15-31. https://doi.org/10.1017/S0025315400014788

Green, J. \& Dales, R.P. (1958) Biliverdin in the eggs of Nereis fucata. Nature, London, 181 (4620), 1412-1413. https://doi.org/10.1038/1811412a0

Dales, R.P. (1959) Pelagic polychaetes from the Malacca Straits and South China Sea. Annals and Magazine of Natural History, Series 13, 2 (20), 481-487. https://doi.org/10.1080/00222935908650880

Dales, R.P. (1960) On the pigments of the Chrysophyceae. Journal of the Marine Biological Association of the United Kingdom, 39 (3), 693-699. https://doi.org/10.1017/S0025315400013655

Dales, R.P. (1961) Observations on the respiration of the sabellid polychaete Schizobranchia insignis. Biological Bulletin, Marine Biological Laboratory Woods Hole, 121 (1), 82-91. https://doi.org/10.2307/1539461

Dales, R. P. (1961) Book Review: The distribution of pelagic polychaetes in the South Atlantic Ocean by N. Tebble. Discovery Reports, Vol. XXX, [pp. 161-300, with 52 figures.] (Cambridge: at the University Press, 1960. 63s. net). Science Progress, 
49 (194), 380-381.

Dales, R.P. (1961) Oxygen uptake and irrigation of the burrow by three terebellid polychaetes: Eupolymnia, Thelepus, and Neoamphitrite. Physiological Zoology, 34 (4), 306-311.

https://doi.org/10.1086/physzool.34.4.30161209

Dales, R.P. (1961) The coelomic and peritoneal cell systems of some sabellid polychaetes. Quarterly Journal of Microscopical Science, 102 (3), 327-346.

Dales, R.P. (1961) A bilatriene pigment in the green terebellid polychaete Eupolymnia heterobranchia (Johnson). Nature, London, 192 (4771), 168. https://doi.org/10.1038/190168a0

Dales, R.P. (1961) Occurrence of Phyllochaetopterus claparedii McIntosh in the North-east Pacific. Nature, London, 192 (4808), 1208-1209. https://doi.org/10.1038/1921208b0

Dales, R.P. (1962) The nature of the pigments in the crowns of sabellid and serpulid polychaetes. Journal of the Marine Biological Association of the United Kingdom, 42 (2), 259-274. https://doi.org/10.1017/S002531540000134X

Dales, R.P. (1962) The polychaete stomodeum and the inter-relationships of the families of Polychaeta. Proceedings of the Zoological Society of London, 139 (3), 389-428. https://doi.org/10.1111/j.1469-7998.1962.tb01837.x

Dales, R.P. (1963) Pelagic polychaetes from waters off the coasts of Kenya and Tanganyika. Annals and Magazine of Natural History, Ser. 13, 6 (68), 501-503. https://doi.org/10.1080/00222936308651387

Dales, R.P. (1963) Pigments in the skins of the polychaetes Arenicola, Abarenicola, Dodecaceria and Halla. Comparative Biochemistry and Physiology, 8 (2), 99-108. https://doi.org/10.1016/0010-406X(63)90072-0

Dales, R.P. (1963) A colorimetric method for the quantitative measurement of total lipids in tissues. Nature, London, 197 (4872), 1120-1121. https://doi.org/10.1038/1971120a0

Dales, R.P. (1963) Accumulation of haematins by polychaetes. Nature, London, 197 (4874), 1302. https://doi.org/10.1038/1971302a0

Dales, R.P. (1963) Book Review: Earthworm Physiology - The Physiology of Earthworms by M.S. Laverack. Pergamon Press, Oxford, London, New York and Paris, ix +206. https://doi.org/10.1038/199314b0

Dales, R.P. (1963) Annelids. Hutchinson University Library, London, 200 pp.

Dales, R.P. (1964) The coelomocytes of the terebellid polychaete Amphitrite johnstoni. Quarterly Journal of Microscopical Science, 105 (2), 263-279.

Dales, R.P. (1965) Iron compounds in the heart-body of the terebellid polychaete Neoamphitrite figulus. Journal of the Marine Biological Association of the United Kingdom, 45 (2), 341-351. https://doi.org/10.1017/S0025315400054874

Mangum, C.P. \& Dales, R.P. (1965) Products of haem synthesis in polychaetes. Comparative Biochemistry and Physiology, 15 (2), 237-257 https://doi.org/10.1016/0010-406X(65)90349-X

Dales, R.P., (1966) Symbiosis in marine organisms. In: Henry, S.M. (Ed.) Symbiosis. Academic Press, New York, pp. 299324.

Bertin, L., Burton, M., Cooke, J.A.L., Cox, F.E.G., Dales, R.P., Davies, R.G., Dawes, B., Frazer, J.F.D., Green, J., Hawkins, S., Jones, J.W., Yonge, C.M. \& Walker, P. (1967) Larousse Encyclopedia of Animal Life. Paul Hamlyn, London, 640 pp.

Dales, R.P. (1967) Sipunculoids (Phylum Sipunculoidea), Echiuroid Worms (Phylum Echiuroidea), Segmented Worms (Phylum Annelida). In: Bertin, L., Burton, M., Cooke, J.A.L., Cox, F.E.G., Dales, R.P., Davies, R.G., Dawes, B., Frazer, J.F.D., Green, J., Hawkins, S., Jones, J.W., Yonge, C.M. \& Walker, P. (Eds.), Larousse Encyclopedia of Animal Life. Paul Hamlyn, London, pp. 95, 96, 97-106.

Dales, R.P. (1967) Annelids (Second Edition). Hutchinson University Library, London, 200 pp.

Lee, W.L., Gilchrist, B.M. \& Dales, R.P. (1967) Carotenoid pigments in Sabella penicillus. Journal of the Marine Biological Association of the United Kingdom, 47 (1), 33-37. https://doi.org/10.1017/S0025315400033531

Dales, R.P. (1968) Conversion of $\delta$-Amino Laevulinic Acid to Porphobilinogen by different tissues of the polychaete annelid Neoamphitrite figulus. Nature, London, 217 (5128), 553. 
https://doi.org/10.1038/217553a0

Dales, R.P. (1968) Book Review: Polychaeta in Africa - A Monograph on the Polychaeta of Southern Africa By J.H. Day. Part 1: Errantia. Pp. viii+1-458. Part 2: Sedentaria. Pp. 459-878. (London: British Museum (Natural History), 1967.) 300s. the two parts. Nature, London, 217 (5134), 1187-1188.

https://doi.org/10.1038/2171187c0

Kennedy, G.Y. \& Dales, R.P. (1968) Formation of uroporphyrin from porphobilinogen by the heart-body tissue and coelomocytes of the polychaete Neoamphitrite figulus. Journal of the Marine Biological Association of the United Kingdom, 48 (1), $77-79$. https://doi.org/10.1017/S0025315400032422

Dales, R.P. (1969) Respiration and energy metabolism in annelids. In: Florkin, M. \& Scheer, B.T. (Eds.), Chemical Zoology. 4. Annelida, Echiura and Sipuncula. Academic Press, London, pp. 93-109. https://doi.org/10.1016/B978-0-12-395537-1.50009-9

Cox, F.E.G., Dales R.P., Green, J., Morton, J.E., Nichols, D. \& Wakelin, D. (1969/1970) Practical Invertebrate Zoology: a laboratory manual for the study of the major groups of invertebrates, excluding protochordates (Dales, R.P., Ed.). Sidgwick \& Jackson, London/University of Washington Press, Seattle, $356 \mathrm{pp}$.

Dales, R.P. (1969/1970) Introduction, 3. Coelenterates, 4. Ctenophores, 7.4. Endoprocts, 8. Annelids, 9. Echiuroids, 10. Sipunculids, 12. Lophophorates, 19. Insects. In: Dales, R.P. (Ed) Practical Invertebrate Zoology: a laboratory manual for the study of the major groups of invertebrates, excluding protochordates. Sidgwick \& Jackson, London/University of Washington Press, Seattle, pp. xi-xii, 49-61, 63-64, 102-103, 105-142, 143, 145-146, 211-212, 313-336.

Dales, R.P., Magnum, C.P. \& Tichy, J. C. (1970) Effects of changes in oxygen and carbon dioxide concentrations on ventilation rhythms in onuphid polychaetes. Journal of the Marine Biological Association of the United Kingdom, 50 (2), 365-380. https://doi.org/10.1017/S0025315400004586

Dales, R.P. \& Pell, J. (1970) Cytological aspects of haemoglobin and chlorocruorin synthesis in polychaete annelids. Zeitschrift für Zellforschung und mikroskopische Anatomie, 109, 20-32. https://doi.org/10.1007/BF00364928

Dales, R.P. \& Pell, J. (1970) The nature of the peritrophic membrane in the gut of the terebellid polychaete Neoamphitrite figulus. Comparative Biochemistry and Physiology, 34 (4), 819-822. https://doi.org/10.1016/0010-406X(70)91003-0

Dales, R.P. (1970) Book Review: Comparative Zoology - Principles of Comparative Anatomy of Invertebrates By W. N. Beklemishev. Translated by J. M. Maclennan. Edited by Z. Kabata. Vol. 1: Promorphology. Pp. xxx + 490. Vol. 2: Organology. Pp. vii + 529. (Oliver and Boyd: Edinburgh, February 1970.) 200s the set. Nature, London, 225 (5237), 1079-1080. https://doi.org/10.1038/2251079a0

Dales, R.P. (1970) Book Review: Spongology - The Biology of the Porifera. Edited by W.G. Fry. (Symposia of the Zoological Society of London, No. 25.) pp. xxviii + 512. (Academic: London and New York, May 1970.) 150s; \$22.50. Nature, London, 227 (5261), 980.

https://doi.org/10.1038/227980a0

Dales, R.P. (1970) Book Review: Life Between the Tides - Biology of Intertidal Animals By R.C. Newell. Pp. viii + 555 (Logos in association with Elek Books: London, 1970.) 160s. Nature, London, 227 (5263), 1169. https://doi.org/10.1038/2271169a0

Dales, R.P. (1970) Book Review: Nitrogen Metabolism Compared - Comparative Biochemistry of Nitrogen Metabolism. Vol. 1: The Invertebrates. Edited by J. W. Campbell. Pp. xiii + 493. (Academic: London and New York, September 1970.) 150s. Nature, London, 228 (5277), 1235. https://doi.org/10.1038/2281235a0

Dales, R.P. (1971) Bioluminescence in pelagic polychaetes. Journal of the Fisheries Research Board of Canada, 28 (10), 1487-1489.

https://doi.org/10.1139/f71-228

Dales, R.P. \& Pell, J. (1971) The origin and nature of the brown substance in the gut caeca of the polychaetes Aphrodite aculeata and Gattyana cirrosa. Journal of Zoology, 163 (3), 413-419. https://doi.org/10.1111/j.1469-7998.1971.tb04541.x

Dales, R.P. (1972) Burrows. New Scientist, 53 (781), 292-293.

Dales, R.P. (1972) Book Review: Invertebrate Compendium - The Invertebrate Panorama. By J. E. Smith, J. D. Carthy, Garth Chapman, R. B. Clark and David Nichols. Pp. $x+406+28$ plates. (Weidenfeld and Nicolson, November 1971.) £7.25. Nature, London, 237(5352), 240.

https://doi.org/10.1038/237240b0

Dales, R.P. (1972) Book Review: Invertebrate Structure - Textbook of Zoology: Invertebrates. Edited by A.J. Marshall and W.D. 
Williams. Seventh edition of A Textbook of Zoology Vol. 1. By the late T. Jeffrey Parker and the late William A. Haswell. Pp. xix + 874. (Macmillan: London and Basingstoke, May 1972.) £5.70. Nature, London, 239(5371), 349.

https://doi.org/10.1038/239349a0

Dales, R. (1972) Book Review: Fourth European Marine Biology Symposium edited by D.J. Crisp. Cambridge University Press, pp 600, £12.40. New Scientist, 53(780), 227.

Dales, R.P. \& Peter, G. (1972) A synopsis of the pelagic Polychaeta. Journal of Natural History, 6(1), 55-92. https://doi.org/10.1080/00222937200770071

Dales, R.P. (1973) Book Review: Nemerteans By Ray Gibson. Pp. 224. (Hutchinson: London, August 1972.) $£ 3$ hardback; £1.75 paperback. Nature, London, 241(2384), 74. https://doi.org/10.1038/241074b0

Dales, R.P. (1973) In Praise of Zoology (Inaugural lecture 1 November 1973), Bedford College, London, 16 pp.

Wells, R.M.G. \& Dales, R.P. (1974) Oxygenational properties of haemerythrin in the blood of Magelona papillicornis Müller (Polychaeta: Magelonidae). Comparative Biochemistry and Physiology, 49A, 57-64. https://doi.org/10.1016/0300-9629(74)90541-6

Dales, R.P. (1974) Book Review: Reproduction of Marine Invertebrates. Vol. 1: Acoelomate and Pseudocoelomate Metazoans. Edited by Arthur C. Giese and John S. Pearse. Pp. xi+546. (Academic: New York and London, 1974.) \$38; £13.45. Nature, London, 251(5475), 556. https://doi.org/10.1038/251556b0

Wells, R.M.G. \& Dales, R.P. (1975) Haemoglobin function in Terebella lapidaria L., an intertidal terebellid polychaete. Journal of the Marine Biological Association of the United Kingdom, 55(1), 211-220. https://doi.org/10.1017/S002531540001585X

Wells, R.M.G. \& Dales, R.P. (1975) The respiratory significance of chlorocruorin. In: Barnes, H. (Ed.), Proceedings of the Ninth European Marine Biology Symposium, Oban, Scotland, 1974 Aberdeen University Press, Aberdeen, pp. 673-681.

Wells, R.M.G. \& Dales, R.P. (1976) Subunit organisation in the respiratory proteins of the Polychaeta. Comparative Biochemistry and Physiology, 54A(4), 387-394. https://doi.org/10.1016/0300-9629(76)90036-0

Wells, R.M.G. \& Dales, R.P. (1976) A preliminary investigation into the oxygen-combining properties of pogonophore haemoglobin. Comparative Biochemistry and Physiology, 54A(4), 395-396. https://doi.org/10.1016/0300-9629(76)90037-2

Dales, R.P. (1976) Book Review: Understanding invertebrates - A Functional Anatomy of Invertebrates. By V. Fretter and A. Graham. Pp. vi+589. (Academic: London and New York, March 1976.) £12.50; \$31. Nature, London, 263(5572), 83. https://doi.org/10.1038/263083a0

Dales, R.P. (1977) The polychaete stomodeum and phylogeny. In: Reish, D.J. \& Fauchald, K. (Eds), Essays on polychaetous annelids in memory of Dr. Olga Hartman. Allan Hancock Foundation Special Publication, University of Southern California, Los Angeles, pp. 525-546.

Dales, R.P. (1977) Book Review: Adaptation to marine life - Adaptation to Environment: Essays on the Physiology of Marine Animals. Edited by R. C. Newell, Pp. 539. (Butterworths: London and Boston, Massachusetts, November 1976.$) £ 25$. Nature, London, 265 (5595), 665. https://doi.org/10.1038/265665a0

Dales, R.P. (1978) Second-set graft rejections: Do they occur in invertebrates? In: Curtis, A.S.G. (Ed.) Cell-Cell Recognition. Symposia of the Society for Experimental Biology, 32, Cambridge University Press, London \& New York, pp. 203-219.

Dales, R.P. (1978) The basis of graft rejection in the earthworms Lumbricus terrestris and Eisenia foetida. Journal of Invertebrate Pathology, 32 (3), 264-277. https://doi.org/10.1016/0022-2011(78)90189-1

Dales, R.P. (1978) Why three? New Scientist, 77(1091), 530.

Dales, R.P. (1978) Defence mechanisms. In: P.J. Mill (Ed.), Physiology of Annelida. Academic Press, London \& New York, pp. 479-507.

Dales, R.P. (1979) Defence of invertebrates against bacterial infection. Journal of the Royal Society of Medicine, 72 (9), $688-$ 696. https://doi.org/10.1177/014107687907200912

Dales, R.P. (1979) Book Review: Biology of the intertidal zone - Biology of Intertidal Animals. By R.C. Newell. Third edition. Pp. 781. (Marine Ecological Surveys: Faversham, UK, 1979.) £22. Nature, London, 279 (5715), 744. https://doi.org/10.1038/279744a0

Knight-Jones, P., Knight-Jones, E.W. \& Dales, R.P. (1979) Spirorbidae (Polychaeta Sedentaria) from Alaska to Panama. Journal of Zoology, 189 (4), 419-458. 
https://doi.org/10.1111/j.1469-7998.1979.tb03973.x

Dales, R.P. \& Dixon, L.J.R. (1980) Responses of polychaete annelids to bacterial infection. Comparative Biochemistry and Physiology, 67A (3), 391-396.

https://doi.org/10.1016/S0300-9629(80)80014-4

Dales, R.P. \& Warren, L.M. (1980) Survival of hypoxic conditions by the polychaete Cirriformia tentaculata. Journal of the Marine Biological Association of the United Kingdom, 60 (2), 509-516. https://doi.org/10.1017/S0025315400028526

Warren, L.M. \& Dales, R.P. (1980) Glucose degradation in the polychaete annelid Owenia fusiformis Delle Chiaje under anaerobic conditions. Comparative Biochemistry and Physiology, 65B (2), 443-445. https://doi.org/10.1016/0305-0491(80)90046-2

Dales, R.P. (Ed.) (1981) Practical Invertebrate Zoology: a laboratory manual for the study of the major groups of invertebrates, excluding protochordates (2 ${ }^{\text {nd }}$ Edition). Blackwell Scientific Publications, Oxford, $356 \mathrm{pp}$.

Dales, R.P. (1981) Introduction to the First Edition; 3, Coelenterates; 4, Ctenophores; 7.4, Endoprocts; 8, Annelids; 9, Echiuroids; 10, Sipunculids; 12, Lophophorates; 19, Insects. In: Dales, R.P. (Ed) Practical Invertebrate Zoology: a laboratory manual for the study of the major groups of invertebrates, excluding protochordates (2 ${ }^{\text {nd }}$ Edition). Blackwell Scientific Publications, Oxford, pp. xi-xii, 49-61, 63-64, 102-103, 105-142, 143, 144-145, 211-212, 313-336.

Dales, R.P. (1981) Aspects of the evolution and development of body cavities, circulatory systems and 'blood cells'. In: Ratcliffe, N.A. \& Rowley, A.F. (Eds), Invertebrate blood cells, Volume 1. General aspects, animals without true circulatory systems to cephalopods. Academic Press, New York, pp. 3-16.

Dales, R.P. \& Dixon, L.J.R. (1981) Polychaetes. In: Ratcliffe, N.A. \& Rowley, A.F. (Eds), Invertebrate blood cells, Volume 1. General aspects, animals without true circulatory systems to cephalopods. Academic Press, New York, pp. 35-74.

Wells, R.M.G., Dales, R.P. \& Warren, L.M. (1981) Oxygen equilibrium characteristics of the erythrocruorin (extracellular haemoglobin) from Owenia fusiformis Delle Chiaje (Polychaeta: Oweniidae). Comparative Biochemistry and Physiology, $70 \mathrm{~A}(1), 111-113$. https://doi.org/10.1016/0300-9629(81)90405-9

Dales, R.P. (1981) Book Review: Marine Invertebrates of California. Robert H. Morris, Donald P. Abbott and Eugene C. Haderlie, with 31 text contributors. Stanford, Stanford University Press, 1980. 928 pp., 900 figures, \$30. ISBN 0-80471045-7. Journal of Molluscan Studies, 47 (3), 344.

Dales, R. P. (1982) Hemagglutinins and hemolysins in the body fluids of Neoamphitrite figulus and Arenicola marina (Annelida: Polychaeta). Comparative Biochemistry and Physiology, 73A (4), 663-667. https://doi.org/10.1016/0300-9629(82)90272-9

Dales, R.P. (1982) Book Review: Invertebrate Respiration. Studies in Biology No 127: by R M G Wells. pp 80. Edward Arnold, London. 1981. £2.25. Biochemical Education, 10 (1), 40. https://doi.org/10.1016/0307-4412(82)90050-4

Dales, R. (1982) The older houses of Warnham: an introduction to the timber-framed buildings which may be seen throughout the parish. Warnham Historical Society, Horsham, 36 pp. Available from: https://www.warnhamsociety.org.uk/History/ TheOlderHousesOfWarnham.pdf (Accessed 1 June 2020)

Dales, R.P. (1983) Observations on granulomata in the polychaetous annelid Nereis diversicolor. Journal of Invertebrate Pathology, 42(2), 288-291. https://doi.org/10.1016/0022-2011(83)90077-0

Dales, R.P. (1984) Blood and coelomic fluid in relation to internal defense in polychaete annelids. In: Cheng, T.C. (Ed.), Comparative Pathobiology, Vol. 6. Invertebrate Blood: Cells and Serum Factors, Springer US, pp. 41-48. https://doi.org/10.1007/978-1-4684-4766-8_3

Braunbeck, T. \& Dales, R.P. (1984) The role of the heart-body and of the extravasal tissue in disposal of foreign cells in two polychaete annelids. Tissue and Cell, 16 (4), 557-563. https://doi.org/10.1016/0040-8166(84)90030-2

Çotuk, A. \& Dales, R.P. (1984) The effect of the coelomic fluid of the earthworm Eisenia foetida Sav. on certain bacteria and the role of the coelomocytes in internal defence. Comparative Biochemistry and Physiology, 78A (2), 271-275. https://doi.org/10.1016/0300-9629(84)90145-2

Çotuk, A. \& Dales, R.P. (1984) Lysozyme activity in the coelomic fluid and coelomocytes of the earthworm Eisenia foetida Sav. in relation to bacterial infection. Comparative Biochemistry and Physiology, 78A (3), 469-474. https://doi.org/10.1016/0300-9629(84)90580-2

Braunbeck, T. \& Dales, R.P. (1985) The ultrastructure of the heart-body and extravasal tissue in the polychaete annelids Neoamphitrite figulus and Arenicola marina. Journal of the Marine Biological Association of the United Kingdom, 65 (3), 653-662. 
https://doi.org/10.1017/S0025315400052498

Dales, R.P. \& Cummings, M.O. (1987) The ultrastructure of the heart-body of the lugworm, Arenicola marina. Journal of the Marine Biological Association of the United Kingdom, 67 (3), 647-652.

https://doi.org/10.1017/S0025315400027351

Dales, R.P. \& Cummings, M.O. (1987) Role of the nephridia in the elimination of foreign cells from the coelomic fluid of two polychaete annelids, with observations on the structure of the nephridia. Tissue and Cell, 19 (3), 387-397. https://doi.org/10.1016/0040-8166(87)90034-6

Dales, R. \& Gilchrist, B. (1987) History of the Zoology Department, Bedford College, 1849-1985. RP Dales, 42 pp.

Pleijel, F. \& Dales, R.P. (1991) Polychaetes: British Phyllodocoideans, Typhloscolecoideans and Tomopteroideans. Synopses of the British Fauna, New Series, 45. Universal Book Services/Dr. W. Backhuys, Oegstgeest, 202 pp.

Dales, R.P. (1992) Phagocyte interactions in echinoid and asteroid echinoderms. Journal of the Marine Biological Association of the United Kingdom, 72 (2), 473-482. https://doi.org/10.1017/S0025315400037838

Dale, R.P. \& Kalaç, Y. (1992) Phagocytic defence by the earthworm Eisenia foetida against certain pathogenic bacteria. Comparative Biochemistry and Physiology, 101A (3), 487-490. https://doi.org/10.1016/0300-9629(92)90499-G

Dales, R.P. (1993) Behavior of Eisenia foetida coelomocytes in Vitro. Journal of Invertebrate Pathology, 61 (3), $331-332$. https://doi.org/10.1006/jipa.1993.1064

Dales, R.P. (2003) Pretty in Pink. New Scientist, 180(2416), 65.

Dales, R.P. (2007) Geranium pylsovianum, G. orientalitibeticum. Geraniaceae Group News, 102, 14.

Dales, R.P. \& Clifton, R. (2007) Geranium pylzovianum, G. orientalitibeticum. Geraniaceae Group News, 107, autumn.

Dales, R.P. (2012) Feedback: 'Handwritten letter to the Editor, Dr Pulsford, 31.10.11'. JMBA Global Marine Environment, 15, 55.

Dales, R.P. (2015) Feeding Mechanisms (Invertebrate). In: AccessScience. McGraw-Hill Education. Available from https:// www.accessscience.com/content/feeding-mechanisms-invertebrate/252300 (Accessed 1 June 2020)

Dales, R.P. (2018) The Buildings of Warnham: A history of a parish in the Weald of West Sussex. Foundry Press, Horsham, West Sussex. 184 pp. Available from https://warnhamsociety.org.uk/History/BuildingsofWarnham-Web.pdf (Accessed 1 June 2020).

\section{Other references (by author)}

Alexander, R.M. (1968) Animal Mechanics. Sidgwick \& Jackson, London, 346 pp.

Alexander, R.M. (1989) Engineering in Zoology [Citation Classic: Alexander, R.M. Animal mechanics. London: Sidgwick \& Jackson. 1968. 346 p.]. Current Contents, 16, 16.

Anon (1959) Zoologist to give All-College talk. El Gauchito, Associated Students of University of California, Santa Barbara College, Summer Session (July 16, 1959), 1 \& 3. Available from: https://www.alexandria.ucsb.edu/lib/ark:/48907/f3pz5bk9 (Accessed 5 June 2020)

Anon (1968) Obituary: Professor G.E. Newell. Nature, London, 219 (5160), 1291. https://doi.org/10.1038/2191291b0

Barnes, R.D. (1968) Invertebrate Zoology (2nd Edition). W.B. Saunders, Philadelphia, 743 pp.

Barnes, R.D. (1969) Bibliography: Invertebrate Zoology. BioScience, 19 (12), 1131-1132. https://doi.org/10.2307/1294886

Bennett, K. (1989) The role of agglutinins in the coelomic fluid of the oligochaete Eisenia foetida. PhD Thesis, University of London, 194 pp. Available from https://repository.royalholloway.ac.uk/items/ee9e00fe-bfee-444f-b64a-a2d0a3348de1/1/ (Accessed 19 July 2020).

Bernal, J.D. (1958) Dr. Rosalind E. Franklin. Nature, London, 182 (4629), 154. https://doi.org/10.1038/182154a0

Bertin, L., Burton, M., Cooke, J.A.L., Cox, F.E.G., Dales, R.P., Davies, R.G., Dawes, B., Frazer, J.F.D., Green, J., Hawkins, S., Jones, J.W., Yonge, C.M. \& Walker, P. (1967) Larousse Encyclopedia of Animal Life. Paul Hamlyn, London, 640 pp. + 64 plates.

Brookhout, C.G. (1964) Annelids. By R. Phillips Dales. Hillary House, New York. \$3.00. 200 pp.; ill. 1963. The Quarterly Review of Biology, 39 (4), 404.

https://doi.org/10.1086/404380

Dixon, D.R. (1977) The energetics of the brackish water serpulid polychaete Mercierella enigmatica Fauvel. PhD Thesis, 
University of London, 494 pp. Available from: https://repository.royalholloway.ac.uk/items/d9e2f372-56dd-4c12-877e214f3b8a28a1/1/ (Accessed 20 May 2020)

Dixon, D.R., Lowe, D.M., Miller, P.I., Villemin, G.R., Colaço, A., Serrão-Santos, R. \& Dixon, L.R.J. (2006) Evidence of seasonal reproduction in the Atlantic vent mussel Bathymodiolus azoricus, and an apparent link to the timing of photosynthetic primary production. Journal of the Marine Biological Association of the United Kingdom, 86 (6), 1363-1371. https://doi.org/10.1017/S0025315406014391

Dudley, P.L. (1964) Some gastrodelphyid copepods from the Pacific Coast of North America. American Museum Novitates, 2194, 1-51.

Dustman, J.H. (1970) Book Review: Practical Invertebrate Zoology, ed. by R. Phillips Dales. 1970. University of Washington Press. Seattle. 368 pp. \$9.50. The American Biology Teacher, 32 (6), 379. https://doi.org/10.2307/4443142

Evans, F. (1997) On the old oceanographers (1). Porcupine Newsletter, 6 (7), 178-179. Available from: http://pmnhs.co.uk/ newsletters (Accessed 12 October 2020)

Fauchald, K. \& Rouse, G.W. (1997) Polychaete Systematics: Past and present. Zoologica Scripta, 26 (2), $71-138$. https://doi.org/10.1111/j.1463-6409.1997.tb00411.x

Fogg, G.E. (1986) George Philip Wells. 17 July 1901 - 27 September 1985. Biographical Memoirs of Fellows of the Royal Society, 32, 650-676. https://doi.org/10.1098/rsbm.1986.0022

Friedrich, H. (1969) Marine Biology: An introduction to its problems and results (Translated by H. Gwynne Vevers). Sidgwick \& Jackson, London, $450 \mathrm{pp}$.

Funderburk, J. \& Hoddle, M. (2011) Laurence Alfred Mound and his contributions to our knowledge of the Thysanoptera. Zootaxa, 2896, 9-36.

https://doi.org/10.11646/zootaxa.2896.1.3

Gordon, D.P. \& Ballantine, B. (2013) Contribution of the Leigh Marine Laboratory to knowledge of marine species diversity. New Zealand Journal of Marine and Freshwater Research, 47 (3), 277-293. https://doi.org/10.1080/00288330.2013.810159

Gray, P. (1967) Book Review: Guide to the Animal Kingdom - The Larousse Encyclopedia of Animal Life. McGraw-Hill, New York, 1967. 640 pp. illus. \$22.50 until Dec.; thereafter, \$25. Science, New Series, 158 (3803), 898-899. https://doi.org/10.1126/science.158.3803.898-a

Green. J. (1961) A new species of Sabellacheres (Crustacea: Copepoda) parasitic on the fan worm Eudistylia polymorpha (Johnson). Proceedings of the Zoological Society of London, 136 (4), 623-628. https://doi.org/10.1111/j.1469-7998.1961.tb05896.x

Green, J. (1968) The Biology of Estuarine Animals. Sidgwick \& Jackson, London, 401 pp.

Harman, W.J. (1971) Book Review: Dales, R. Phillips, ed. Practical Invertebrate Zoology. 356 pp. University of Washington Press, 1970. \$9.50. American Scientist, 59 (3), 372.

Hollom, P.A.D. (1951) Great Crested Grebe Sample Census: Report to end of 1950. British Birds, 44 (11), 361-369.

Hutchings, P.A. (1970) Reproductive biology of the polychaete Melinna cristata off the Northumberland coast. PhD Thesis, University of Newcastle upon Tyne, $150 \mathrm{pp}$.

Kent, R.M.L. (1977) The infestation of molluscs by Polydora spp. PhD Thesis, University of Plymouth, 245 pp. Available from: https://pearl.plymouth.ac.uk/handle/10026.1/582 (Accessed 20 July 2020).

Kent, M. (2000) Advanced Biology. Oxford University Press, Oxford, 624 pp.

Mackie, A.S.Y., Oddy, G. \& Morgenroth, H. (2011) Phyllis Knight-Jones - A remarkable life (1933-2009). Proceedings of the $10^{\text {th }}$ International Polychaete Conference, Lecce, Italy 2010. Italian Journal of Zoology, 78(S1), 347-355. https://doi.org/10.1080/11250003.2011.574018

Mackie, A.S.Y., Oddy, G., Knight-Jones, P., Ryland, J.S., Naylor, E. \& Psalti, I.S.M. (2014) Elis Wyn Knight-Jones: pioneering marine biologist and polychaete taxonomist (1916-2012). Proceedings of the $11^{\text {th }}$ International Polychaete Conference, Australian Museum, 2013. Memoirs of Museum Victoria, 71, 367-375. Available from: https://museumsvictoria.com. $\mathrm{au} /$ collections-research/journals/memoirs-of-museum-victoria/volume-71-2014/pages-367-375/ (Accessed 17 November 2020)

Magnum, C.P. (1966) Two species of Clymenella (Polychaeta: Maldanidae) from Brazil. Postilla, 104, 1-10.

Mettam, C.J. (1969) Aspects of polychaete skeletomuscular systems. PhD Thesis, University of Reading.

Moment, G. (1964) Book Review: Zoology - Annelids. R. Phillips Dales. Hutchinson, London; Hillary House, New York, 1963. 200 pp. Illus. \$3. Science, New Series, 145(3633), 697-698.

Moore, P.G. (2009) The University Marine Biological Station Millport: in the beginning was the vision (1970). Notes and Records of the Royal Society, 63, 191-202. 
https://doi.org/10.1098/rsnr.2008.0030

Morton, B. (2011) Obituary: John Morton B.Sc., M.Sc. (Auckland), Ph.D., D.Sc. (London), FRSNZ, QSO (18 July 1923 - 6 March 2011). Molluscan Research, 31 (2), 136-140.

Mustaquim, J. (1982) Biochemical systematics of certain polychaetes with special reference to Polydora ciliata (Johnston). PhD Thesis, University of London, 276 pp. Available from https://repository.royalholloway.ac.uk/items/4edd5c06-1cc6-4d18ad43-5ca2f135ae96/1/ (Accessed 20 May 2020).

Newell, G.P. (1949) Occurrence of Saccoglossus kowalevskyi (?) on the north Kent coast. Nature, London, 164(4174), 747. https://doi.org/10.1038/164747a0

Oppenheimer, J. (1968) Book Review: The Larousse Encyclopedia of Animal Life. Foreword by Robert Cushman Murphy. McGraw-Hill Book Company, New York, London, Toronto, Sydney, Johannesburg. \$25.00. 640 p. + 64 p. pl.; subject index. 1967. The Quarterly Review of Biology, 43 (1), 95. https://doi.org/10.1086/405677

Orrhage, L. (1973) Two fundamental requirements for phylogenetic-scientific works as a background for an analysis of Dales's 1962 and Webb's 1969 theories. Zeitschrift für Zoologische Systematik und Evolutionsforschung, 11, 161-173. https://doi.org/10.1111/j.1439-0469.1973.tb00140.x

Rouse, G.W. \& Fauchald, K. (1997) Cladistics and polychaetes. Zoologica Scripta, 26 (2), 139-204. https://doi.org/10.1111/j.1463-6409.1997.tb00412.x

Tebble, N. (1963) Book Review: Polychaete Physiology - Annelids By R. Phillips Dales. Pp. 200. (London: Hutchinson and Co. (Publishers), Ltd., 1963.) 15s. Nature, London, 200 (4907), 619. https://doi.org/10.1038/200619a0

Tebble, N. (1964) Annelids By R. Phillips Dales. Pp. 200. (London: Hutchinson University Library, 1963. 15s. net. Science Progress, 52 (206), 329.

Trueman, E.R. (1969). Book Review: Techniques for Dissection - Practical Invertebrate Zoology. A Laboratory Manual for the Study of the Major Groups of Invertebrates, excluding Protochordates. By F.E.G. Cox, R. Phillips Dales, J. Green, J.E. Morton, D. Nichols and D. Wakelin. (Biology Series.) Pp. xii + 356. (Sidgwick and Jackson: London, 1969.) 25s. Nature, London, 224 (5223), 993-994. https://doi.org/10.1038/224993c0

Warren, L.M. (1975) The biology of Capitella capitata (Fabricius) and a review of the genus Capitella Blainville. PhD Thesis, University of London, 305 pp. Available from: https://repository.royalholloway.ac.uk/items/f2583314-c484-4d4f-bfe4efc93b3bd311/1/ (Accessed 20 May 2020)

Watson, K. (2016) The 1960s The Decade that Shook Britain. Historic UK. Available from: https://www.historic-uk.com/ CultureUK/The-1960s-The-Decade-that-Shook-Britain (accessed 17 July 2020)

Wells, G.P. (1964) Book Review: R.P. Dales (1963). Annelids. Biological Sciences Series. Pp. 200; 19 text-figures. London: Hutchinson University Library. Price 15s. Journal of Animal Ecology, 33 (2), 376-377.

Wells, R.M.G. (1974) Some aspects of the respiratory physiology of polychaete body fluids - A study in adaptation. PhD Thesis, University of London, 143 pp. Available from: https://repository.royalholloway.ac.uk/items/7ad76161-c3a7-4143-bba7e91557e 75faa/1/ (accessed 20 May 2020)

Yeo, P.F. (2005) Hardy Geraniums: The Complete Guide to the Genus (Revised Edition). B.T. Batsford, London, 220 pp.

\section{Obituaries}

Hamer, J., Dixon, D. \& Dixon, L. (2020) Professor Rodney Dales, zoologist, (1927-2020). Warnham Historical Society, 1 page (8 March 2020).

Dales, C. (2020) Rodney Dales obituary. The Guardian 23 May 2020, Other lives, p. 9. Available from: https://www.theguardian. com/science/2020/mar/30/rodney-dales-obituary (accessed 5 May 2020). 